\title{
Nitric oxide of human colorectal adenocarcinoma cell lines promotes tumour cell invasion
}

\author{
A Siegert*,', C Rosenberg', WD Schmitt', C Denkert' and S Hauptmann' \\ 'Institute of Pathology, Charité Hospital, Humboldt University, Schumannstr 20/21, D-10117 Berlin, Germany
}

The present study investigates the role of nitric oxide and the involvement of nitric oxide synthase II isoform on the invasion of human colorectal adenocarcinoma cell lines HRT-I8 and HT-29. HRT-I 8 cells, which constitutively express nitric oxide synthase II mRNA were three-fold more invasive in a Matrige ${ }^{\circledR}$ invasion assay than nitric oxide synthase $\|$ mRNA negative HT-29 cells. Treatment of HT-29 cells with the nitric oxide donor Deta NONOate (50 nM) as well as induction of nitric oxide synthase II mRNA and production of endogenous nitric oxide by inflammatory cytokines (IFN- $\gamma$ and IL-I $\alpha$ ) increased the invasiveness of HT-29 cells by approximately $40 \%$ and $75 \%$, respectively. In HT-29 cells nitric oxide synthase II mRNA was also induced in co-culture with human monocytes. The invasiveness of HRT-I 8 cells and stimulated HT-29 cells was partly inhibited by the nitric oxide synthase II inhibitor $1400 \mathrm{~W}$. These results show that nitric oxide increases the invasion of human colorectal adenocarcinoma cell lines HRT- 8 and HT-29, and the involvement of nitric oxide synthase II isoform in tumour cell invasion. Therefore, the production of nitric oxide and secretion of pro-inflammatory cytokines by tumour-associated macrophages, which in turn induce nitric oxide synthase II isoform in tumour cells, promotes tumour cell invasiveness. British Journal of Cancer (2002) 86, 1310 - 1315. DOl: 10.1038/sj/bjc/6600224 www.bjcancer.com

(c) 2002 Cancer Research UK

Keywords: nitric oxide; nitric oxide synthase II; tumour cells; monocytes; cytokines

There is no doubt that tumour-associated macrophages (TAM) are an important component of the tumour stroma. They affect the behaviour of tumour cells by a variety of mediators. One of these mediators is nitric oxide (NO). NO is produced by three isoforms of the nitric oxide synthase (NOS I-III) using L-arginine as substrate. In macrophages NOS II is generally inducible by inflammatory stimuli and mediates a high-output long-lasting release of NO. Because NO is the source of reactive nitrogen intermediates (RNI), the NOS II induction is one part of macrophage cytotoxicity against tumour cells. On the other hand, NO favours neoangiogenesis, if NO concentrations do not reach a cytotoxic level (Wink et al, 1998). In human malignant tumours high NO concentrations have been measured in vivo. Although the main source of NO probably are tumour-associated macrophages, there are some reports that the synthesis of NO is inducible by cytokines in some human carcinoma cell lines like DLD-1, HT-29, A-172 and NIH:OVCAR-3 (Thomsen and Miles, 1998). The biological significance of NO in malignant tumours is not clear, but a recent study suggest that a high expression of NOS II and NOS III is associated with aggressive behaviour of colorectal adenocarcinomas (Yagihashi et al, 2000). The aim of the present study was to investigate if NO is able to modulate tumour cell invasiveness of human colorectal adenocarcinoma cell lines (HRT-18 and HT-29), and whether NO can be induced by cytokines produced by stromal macrophages.

*Correspondence: A Siegert; E-mail: antje.siegert@charite.de Received 10 September 200I; revised 18 December 2001; accepted 31 January 2002

\section{MATERIALS AND METHODS}

\section{Monocyte isolation}

Monocytes were isolated from buffy coats with Ficoll-Paque (Pharmacia, Freiburg, Germany) followed by hypotonic density gradient centrifugation in Percoll (Pharmacia) as previously described in detail (Feige et al, 1982). Prior co-culture experiments pooled monocytes were cultivated for $24 \mathrm{~h}$ in hydrophobic Teflon bags (Heraeus, Osterode, Germany) in RPMI-1640 medium (Biochrom, Berlin, Germany) with $10 \%$ human $\mathrm{AB}$ serum (PAA, Cölbe, Germany) and $1 \%$ glutamine (PAA) at a cell density of $2 \times 10^{6}$ per ml. About $80 \%$ of these cells were monocytes, as shown by non-specific esterase activity (Sigma, Deisenhofen, Germany).

\section{Tumour cells}

The human colorectal adenocarcinoma cell lines HRT-18 and HT29 were obtained from the Cell Lines Service (Heidelberg, Germany) and maintained in McCOY's 5A medium (Gibco, Eggenstein, Germany) supplemented with $10 \%$ foetal calf serum (PAA).

\section{Co-culture of HT-29 cells and monocytes}

HT-29 cells and monocytes co-culture was performed in $7.5 \mathrm{~cm}$ transwell plates with cell-impermeable membranes (pore size $0.4 \mu \mathrm{m}$, Corning Costar) in McCOY's 5A medium. Monocytes were added onto the transwell membrane above a subconfluent HT-29 monolayer in a monocyte:tumour cell ratio of $2: 1$. For RT-PCR total RNA was separately isolated from HT-29 cells and monocytes after 4, 8, 24 and 48 h of co-culture and monoculture. For nitrite determination supernatants were harvested in parallel, centrifuged and frozen at $-20^{\circ} \mathrm{C}$. 


\section{Induction of NOS II in HT-29 cells}

Subconfluent monolayers were cultured in serumfree McCOY's 5A medium for $24 \mathrm{~h}$. Thereafter, different concentrations of human $r \mathrm{IFN}-\gamma$ (Sigma) and human $r \mathrm{IL}-1 \alpha$ (Tebu, Frankfurt, Germany) were added with fresh medium. After $72 \mathrm{~h}$ total RNA was isolated, and supernatants were collected.

Reverse transcription - polymerase chain reaction (RT PCR); Reverse transcription - multiplex polymerase chain reaction (RT - MPCR)

For both total RNA was isolated by the phenol/isothiocyanate method using Trizol-reagent (Gibco). RT - PCR: after cDNA synthesis efficiency was controlled by PCR for glyceraldehyde-3phosphate-dehydrogenase (GAPDH). The primers used for amplification of GAPDH and NOS II are shown in Table 1. RTMPCR: after cDNA synthesis, CytoXpress MPCR Kit For Human NO Metabolism Genes was used following the manufacturer's recommendations (Biosource International, Camarillo, USA) to detect mRNA of GAPDH, TNF- $\alpha$, IL- $1 \beta$, NOS I-III. Amplification products were separated on 2 or $3 \%$ agarose gels and stained with ethidium bromide.

\section{Measurement of nitrate and nitrite}

Nitrate and nitrite as stable products of NO were measured with the Cayman Chemical Nitrate/ Nitrite Assay Kit (Alexis, Grünberg, Germany) in cell culture supernatants. According to the manufacturer's instruction nitrate was first converted to nitrite and than the Griess Reagents were added, which react to a purple compound. Absorbance, photometrically measured, determines nitrite concentration.

\section{Invasion assay}

Invasion of tumour cells was determined using modified Boyden Chamber technology. Transwells with polycarbonate membranes ( $8 \mu \mathrm{m}$ pore size) in six-well tissue culture plates (Corning Costar, Bodenheim, Germany) were precoated with Matrigel ${ }^{\mathbb{B}}$ Basement Membrane Matrix (Becton Dickinson, Heidelberg, Germany) diluted in serum free McCOY's $5 \mathrm{~A}\left(1 \mathrm{mg} \mathrm{ml}^{-1} ; 675 \mu \mathrm{l}\right.$ per transwell) and were incubated for $2 \mathrm{~h}$ at $37^{\circ} \mathrm{C}$. Thereafter, transwells were rinsed with serum free medium and tumour cells were seeded at a concentration of $1.3 \times 10^{5}$ per $\mathrm{ml}(1.5 \mathrm{ml})$ into the transwell. NO donor or NOS inhibitor was added to the upper and to the lower compartment. After $72 \mathrm{~h}$, cultures were incubated with $0.5 \mathrm{mg} \mathrm{ml}^{-1}$ 3-(4,5-dimethylthiazole-2-yl)-2.5-diphenyltetrazolium bromide (MTT) for $4 \mathrm{~h}$, as described (Imamura et al, 1994). Invasive cells attached to the bottom of the polycarbonate membrane were scrapped off and rinsed into the lower tissue culture well with DMSO. After that, noninvasive cells in the transwell were disolved with DMSO. Formazan solutions were transfered in a 96-well microplate and absorbance was measured at $490 \mathrm{~nm}$ and $690 \mathrm{~nm}$ using an ELISA reader. For each cell line a standard curve was generated to compare invasiveness of different cell lines. Absorbance was plotted against certain numbers of cells and linear regression analysis was performed. Linearity between the absor-

Table I Primers used

\begin{tabular}{llc}
\hline & Primers & $\begin{array}{c}\text { Amplification } \\
\text { product }\end{array}$ \\
\hline GAPDH & 5'-ACCACAGTCCATGCCATCAC-3' & $452 \mathrm{bp}$ \\
\multirow{2}{*}{ NOS I } & 5'-TCCACCACCCTGTTGCTGTA-3' & \\
& 5'-GCAGAATGTGACCATCATGG-3' & $426 \mathrm{bp}$ \\
& 5'-ACAACCTTGGGGTGAAGGC-3' & \\
\hline
\end{tabular}

bance and the number of cells was seen within the range of 100 to $5 \times 10^{4}$ cells per well. All assays were done in triplicate.

\section{NO donor and NOS II inhibitor}

Deta NONOate (NO donor) and 1400 W.2HCL (NOS II inhibitor) were from Alexis (Grünberg, Germany). Deta NONOate was added every $24 \mathrm{~h}$ and $1400 \mathrm{~W}$ only once at the beginning of an assay. Both chemicals showed no effects on proliferation and viability in the used concentrations as seen in direct cell counting using a CASY cell counter (Schärfe Systems, Reutlingen, Germany).

\section{Statistics}

All data shown are from at least three independent experiments and are expressed as mean \pm s.d. Statistical significance was determined by using Student's $t$-test. $P$-values smaller than 0.05 were considered to be significant.

\section{RESULTS}

\section{NOS isoform expression in colorectal adenocarcinoma cell lines HRT-18 and HT-29}

The human colorectal adenocarcinoma cell lines HRT-18 and HT29 were used to investigate the role of NO in tumour cell invasion. The cell lines differ in the expression of the NOS II isoform. As shown by RT-MPCR both cell lines constitutively express NOS I and NOS III mRNA, but HRT-18 cells constitutively express NOS II mRNA, too (Figure 1).

Under non-stimulatory conditions HRT-18 cells generate more NO, measured as nitrite, than HT-29 cells which can be explained by the difference in NOS II expression (Table 2).

\section{Induction of NOS II mRNA in HT-29 cells with a combination of IFN- $\gamma$ and IL- $1 \alpha$}

In HT-29 induction of NOS II mRNA was achieved after incubation with a combination of IFN- $\gamma$ and IL- $1 \alpha$ in a concentration dependent manner as shown by RT-PCR (Figure 2). A strong cytotoxic effect was observed with $300 \mathrm{U} \mathrm{ml}^{-1}$ IFN- $\gamma$ and

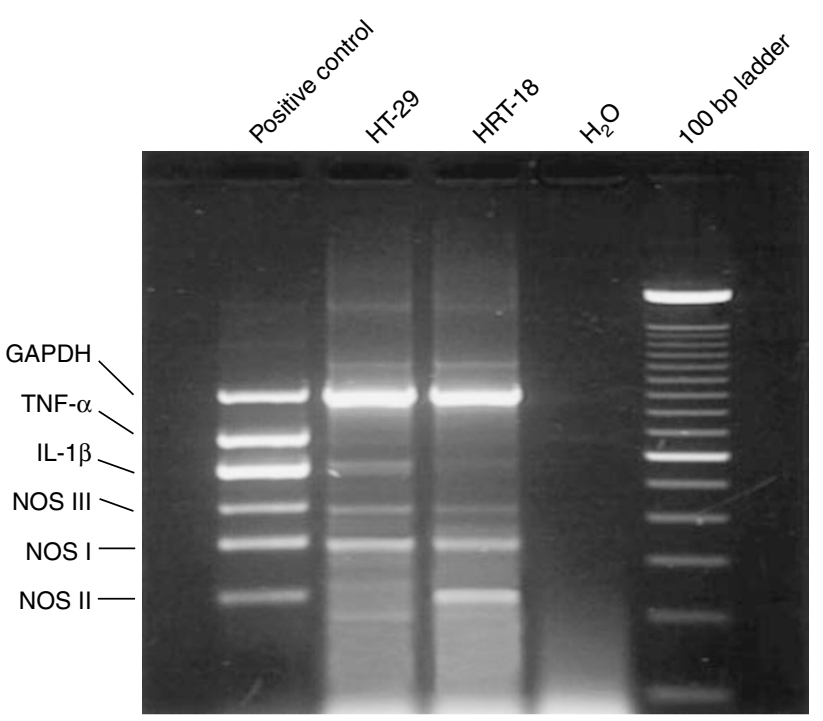

Figure I Multiplex RT-PCR analysis of NOS isoform expression. The presence of NOS I and NOS III mRNA was shown in both human colorectal adenocarcinoma cell lines HT-29 and HRT-I8, NOS II mRNA was only expressed in HRT-I8. 
$10 \mathrm{ng} \mathrm{ml}^{-1} \mathrm{TNF}-\alpha$, which correlates with a strong NOS II mRNA expression.

\section{Induction of NOS II mRNA in HT-29 cells after co-culture with human monocytes}

To investigate whether monocytes are able to induce NO production in NOS II-negative HT-29 tumour cells, co-cultures were

Table 2 Nitrite in supernatants of HRT-I 8 and HT-29 cells

\begin{tabular}{llc}
\hline & HT-29 & HRT-18 \\
\hline $\mathrm{NO}_{2}$ per $10^{6}$ cells per 4 days & $0.15 \mu \mathrm{M}$ & $0.22 \mu \mathrm{M}$ \\
\hline
\end{tabular}

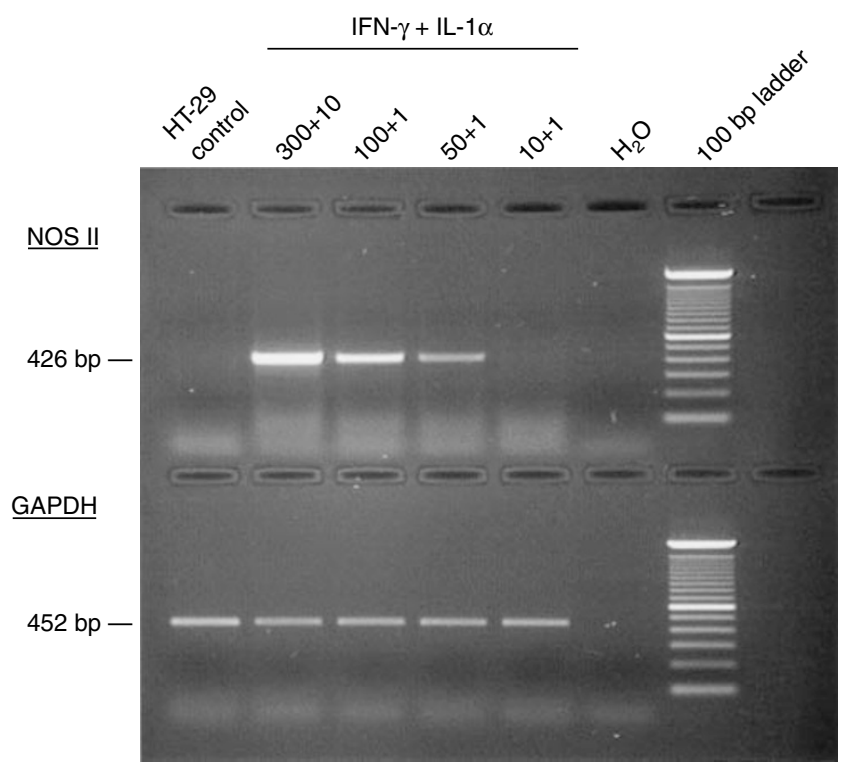

Figure 2 Induction of NOS II mRNA expression in HT-29 cells by cytokines. Cells were treated for $72 \mathrm{~h}$ with different concentrations of a combination of human $r \mathrm{FN}-\gamma\left(300-10 \cup \mathrm{ml}^{-1}\right)$ and human $r \mathrm{lL}-1 \alpha(10-$ $\mathrm{I} \mathrm{ng} \mathrm{ml}^{-1}$ ). RT-PCR showed a cytokine concentration-depending induction of NOS II mRNA. performed in a transwell system, which allows separate RNA analysis of the different cells. After 4, 8, 24 and $48 \mathrm{~h}$ of co-culture, RTPCR showed a strong induction of NOS II mRNA in HT-29 cells, whereas the weak NOS II expression in monocytes remained unchanged (Figure 3). In parallel cultures, total nitrite release was increased at each time point in co-cultures compared to monocytes and tumour cells alone (Table 3).

\section{Invasiveness of HRT-18 and HT-29 cells}

Invasiveness was assessed by a Boyden chamber coated with Matrigel ${ }^{\mathbb{R}}$. Both cell lines were invasive, but the level of invasion in the HRT-18 cell line was three times higher than in the HT-29 cell line (Figure 4). Because a parallelism was seen between the degree of invasiveness and the amount of NO production we further investigated whether a more causative relationship exist.

\section{Inhibition of NO synthesis and invasion of HRT-18 cells by $1400 \mathrm{~W}$}

$1400 \mathrm{~W}$ is an irreversible inhibitor of all NOS isoforms, but has a much higher affinity to NOS II compared to NOS I and NOS III. Potency and selectivity of $1400 \mathrm{~W}$ to NOS II is greater than of any other described NOS II inhibitors (Garvey et al, 1997). $1400 \mathrm{~W}$ $(0.5 \mathrm{~mm})$ inhibited NO synthesis in HRT-18 cell line to approximately $40 \%$, but had no effects on viability or proliferation. Cytotoxic effects were seen with $10 \mathrm{mM} 1400 \mathrm{~W}$ (data not shown).

Inhibition of NO synthesis by $1400 \mathrm{~W}$ was accompanied by a significant reduction of the Matrige ${ }^{\mathbb{R}}$ invasion of the HRT-18 cell line of about $50 \%$ (Figure 5 ).

\section{Stimulation of invasion of HT-29 cells by Deta-NONOate}

Deta NONOate is a NO donor with a half life of $20 \mathrm{~h}$ (Keefer et al, 1996). Two moles NO were released per mole of Deta NONOate.

Table 3 Nitrite in supernatants of monocytes, HT-29 and co-cultures

\begin{tabular}{lrrrr}
\hline & $\begin{array}{c}\mathbf{4} \mathbf{h} \\
(\mu \mathbf{M})\end{array}$ & $\begin{array}{c}\mathbf{8} \mathbf{h} \\
(\mu \mathbf{M})\end{array}$ & $\begin{array}{c}\mathbf{2 4} \mathbf{h} \\
(\mu \mathbf{M})\end{array}$ & $\begin{array}{r}\mathbf{4 8} \mathbf{~ h} \\
(\mu \mathbf{M})\end{array}$ \\
\hline Monocytes alone & 38 & 39 & 39 & 32 \\
HT-29 alone & $<1$ & $<1$ & $<1$ & $<1$ \\
Monocytes+HT-29 co-culture & 49 & 57 & 62 & 63 \\
\hline
\end{tabular}

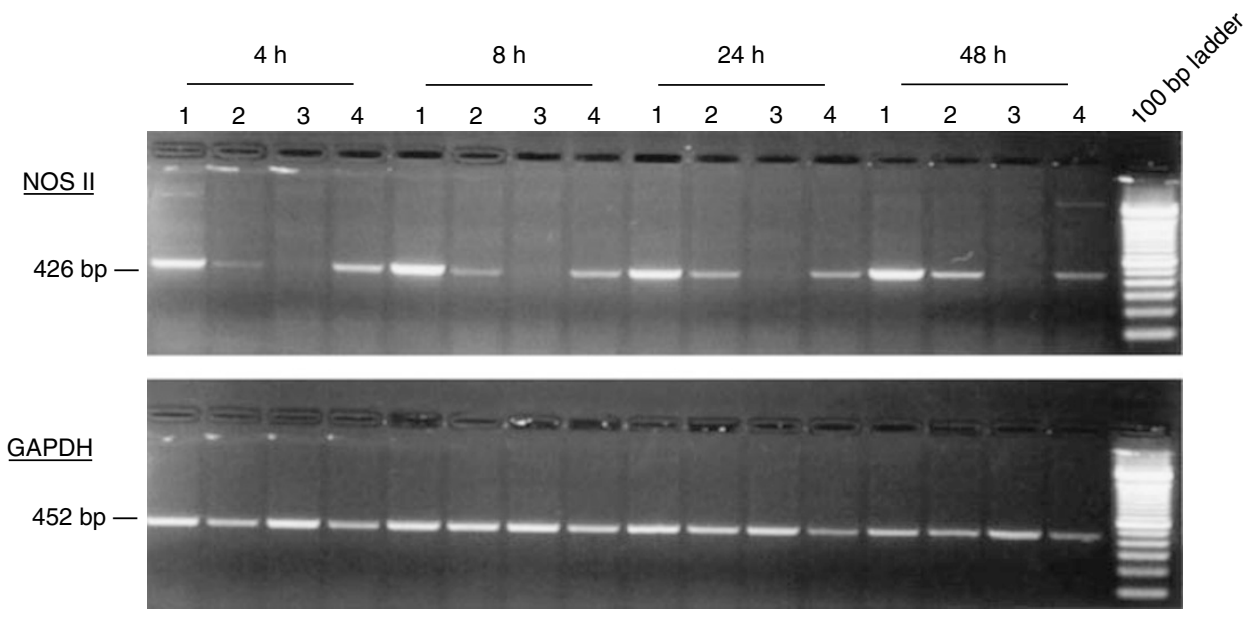

Figure 3 NOS II mRNA expression in HT-29/ monocyte co-cultures. RT-PCR of HT-29 cells (lane I) and monocytes (lane 2) from transwell co-cultures and in parallel of HT-29 (lane 3) and monocytes (lane 4) from monocultures at different time points is shown. Induction of NOS II mRNA was detected in HT-29 cells at each time point of co-culture. GAPDH was used as an internal control. 


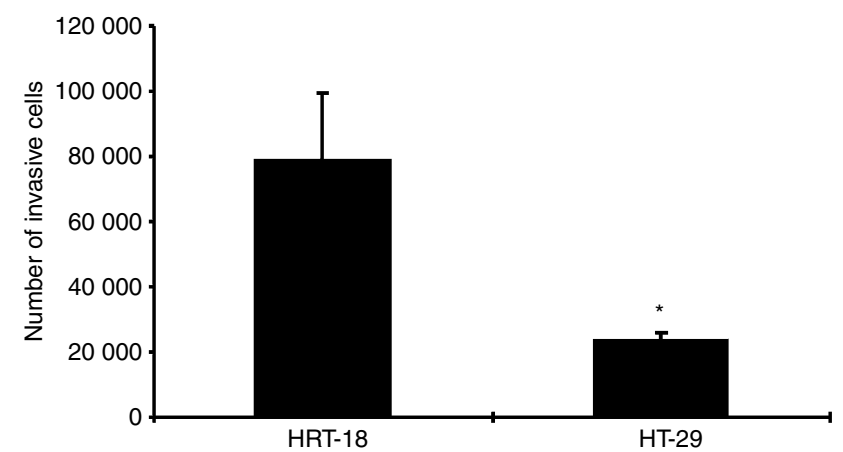

Figure 4 Matrigel $^{\mathbb{B}}$ invasion by the human colorectal adenocarcinoma cell lines HRT-I 8 and HT-29. HRT- 8 cells are more invasive than HT29 cells. Cells were cultured on transwell cell culture inserts coated with Matrige ${ }^{\mathbb{R}}$. After $72 \mathrm{~h}$ cells were treated with MTT, and optical density was measured after disolving the cells with DMSO. Optical density data of invasive cells were converted into cell numbers on the basis of a standard curve for each cell line. Data of one out of three experiments are expressed as mean and standard deviation. *Significant $(P<0.05)$ compared to HRT-I 8 cells.

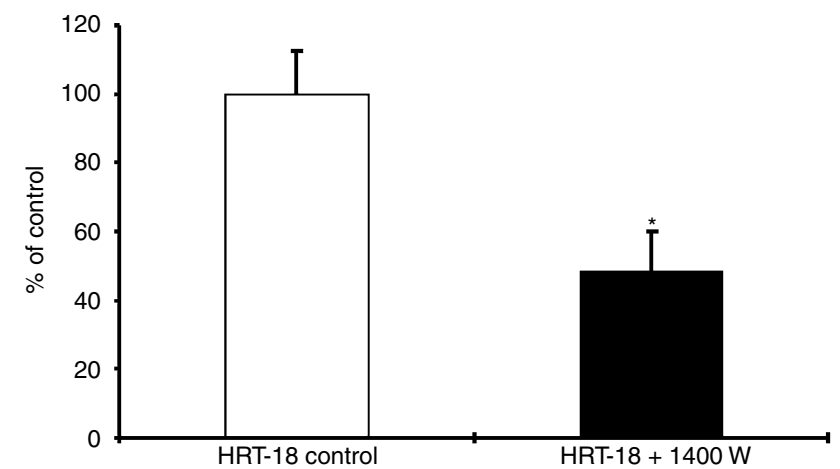

Figure 5 Inhibition of HRT- 18 Matrigel ${ }^{\circledR}$ invasion by $1400 \mathrm{~W}$. HRT- 18 cells were cultured on transwell cell culture inserts coated with Matrigel ${ }^{\mathbb{R}}$ and treated with the NOS II inhibitor I $400 \mathrm{~W}(0.5 \mathrm{~mm})$ for $72 \mathrm{~h}$. Data of invasive cells, mean \pm s.d. of three independent experiments are shown. *Significant $(P<0.05)$ compared to HRT-I 8 untreated cells.

Additional exogenerously derived NO by $50 \mathrm{~nm}$ Deta NONOate every $24 \mathrm{~h}$ to NOS II negative HT-29 cells increased the number of invasive cells about $40 \%$ (Figure 6). This concentration had no effects on viability. Cytotoxic effects were seen with $100 \mu \mathrm{M}$ (data not shown).

\section{Stimulation of invasion of HT-29 cells by a combination of IFN- $\gamma$ and IL-1 $\alpha$}

Induction of NOS II in HT-29 cells by the cytokines IFN- $\gamma$ $\left(100 \mathrm{U} \mathrm{ml}^{-1}\right)$ and IL- $1 \alpha\left(1 \mathrm{ng} \mathrm{ml}^{-1}\right)$ and production of NO by the tumour cells itself significantly increased Matrigel ${ }^{\circledR}$ invasion of HT-29 cells about $75 \%$. This effect was marginally abolished by the NOS II inhibitor $1400 \mathrm{~W}$ (Figure 7), which proves a contribution of NOS II in the process of tumour cell invasion. It also indicates, that cytokines induce NO independent mechanisms of tumour cell invasion.

\section{DISCUSSION}

For some human cancers elevated NOS activity has been reported. The level of NOS protein and/or NOS activity has been positively correlated with the degree of malignancy in human gynaecological

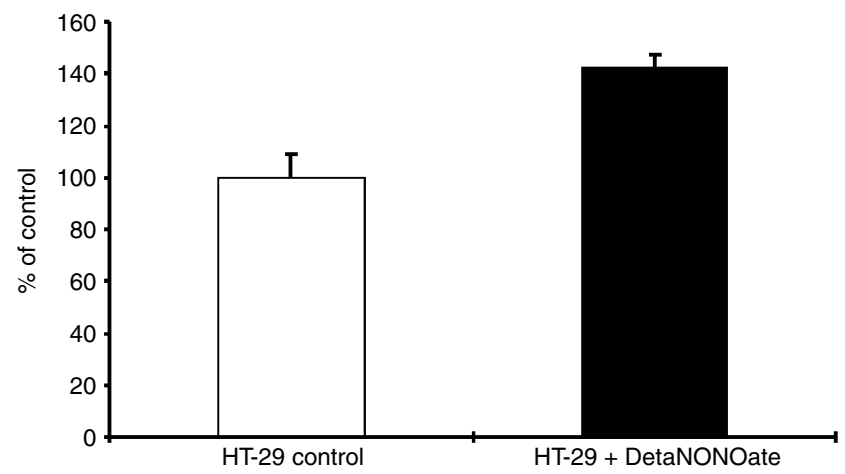

Figure 6 Enhancement of HT-29 Matrigel ${ }^{\mathbb{R}}$ invasion by Deta NONOate. HT-29 cells were cultured on transwell cell culture inserts coated with Matrige ${ }^{\mathbb{R}}$ and treated with the NO donor Deta NONOate (50 nM) for $72 \mathrm{~h}$. Data of invasive cells, mean \pm s.d. of three independent experiments are shown.

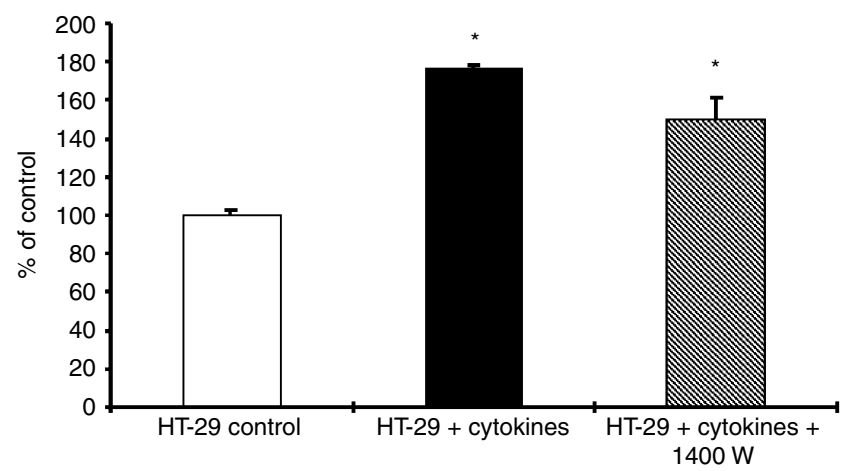

Figure 7 Enhancement of HT-29 Matrige ${ }^{\circledR}$ invasion by cytokines. HT29 cells were cultured on transwell cell culture inserts coated with Matrigel ${ }^{\mathbb{R}}$ and treated with human $r \mid \mathrm{FN}-\gamma\left(100 \cup \mathrm{ml}^{-1}\right)$ and human $r \mathrm{~L}-\mid \alpha$ ( $\mathrm{ng} \mathrm{ml} \mathrm{m}^{-1}$ ) for $72 \mathrm{~h}$. This enhancement was slightly abrogated by addition of the NOS II inhibitor I $400 \mathrm{~W}(0.5 \mathrm{~mm})$. Data of invasive cells, mean \pm s.d. of three independent experiments are shown. *Significant $(P<0.05)$ compared to HT-29 untreated cells.

cancers (Thomsen et al, 1994), central nervous system tumours (Cobbs et al, 1995), breast cancer (Thomsen et al, 1995), squamous-cell carcinomas of the head and neck (Gallo et al, 1998), lung cancer (Fujimoto et al, 1997) and oesophageal squamous cell carcinoma (Tanaka et al, 1999). Obviously, NO plays an ambivalent role in tumorigenesis depending on NOS activity and resulting NO concentrations. Although there are some reports showing induction of tumour cell apoptosis and cytostasis by high levels of NO (Xie and Fidler, 1998), an increasing number of reports shows a positive correlation between $\mathrm{NO}$ and tumour progression (Thomsen and Miles, 1998) explained by NO-stimulated migratory, invasive and angiogenic abilities of tumour cells (Thomsen and Miles, 1998; Lala and Chakraborty, 2001).

This study clearly demonstrates, that NO increases the invasion of the human colorectal adenocarcinoma cell lines HRT-18 and HT-29. HRT-18 cells and HT-29 cells differ in NOS expression and have different invasive capacities. The NOS II negative HT29 cells are less invasive indicating a role of NOS II in Matrigel ${ }^{\mathbb{R}}$ invasion. The invasiveness of HT-29 cells was further enhanced by the exogen addition of $\mathrm{NO}$ or the induction of endogen $\mathrm{NO}$ production by cytokines. In general, NOS II is inducible in a lot of human tumour cell lines by pro-inflammatory cytokines (Thomsen and Miles, 1998). It has been shown too, that bacterial infection of human colon epithelial cells is a sufficient stimulus 
to upregulate their expression of NOS II and NO production (Witthoft et al, 1998). Enhanced expression of NOS II and NOS III has been recently discussed to correlate with tumour growth and vascular invasion in human colorectal cancer (Yagihashi et al, 2000; Lagares-Garcia et al, 2001). In our study the involvement of the NOS II isoform in Matrigel ${ }^{\mathbb{R}}$ invasion of the colorectal adenocarcinoma cell lines was evidenced by the inhibition of invasion by $1400 \mathrm{~W}$, the most selective NOS II inhibitor reported to date. $1400 \mathrm{~W}$ never completely abolished the basal invasion of HRT-18 or the cytokine-stimulated invasion of HT-29, which indicates the existence of other invasion-inducing mechanisms beside the NOS II/NO pathway.

Not investigated in this study were mediators of the NO-stimulated invasion, which lead to essential steps as migration and matrix degradation. Reduced migratory and invasive capacities of the murine mammary cell lines C3L5 and C10 were demonstrated with the NOS inhibitor L-NAME (Jadeski et al, 2000). Furthermore, NO promotes tumour cell invasion in the C3L5 murine mammary adenocarcinoma model by altering the balance between the expression of matrix metalloproteinase-2 (MMP-2) and it's tissue inhibitors-2 and -3 (TIMP 2 and TIMP 3) (Orucevic et al, 1999). Activation of MMP's by NO has also been shown in chondrocytes (Murrell et al, 1995). Together, MMP's and TIMP's modulate the structure of the extracellular matrix (ECM) and changes of their expression level or activation of MMP's weaken the integrity of the ECM, which is a prerequisite for invasion and metastasis (Kohn and Liotta, 1995).

Tumour-associated macrophages are the source of various cytokines within malignant tumours, which can induce NOS II mRNA expression. There is an earlier report describing the induction of NOS II mRNA in co-cultures of the human urothelial bladder carcinoma cell line RT4 and human monocytes (Konur et al,

\section{REFERENCES}

Bogdan C, Nathan C (1993) Modulation of macrophage function by transforming growth factor $\beta$, interleukin-4, and interleukin-10. Ann NY Acad Sci 685: $713-739$

Cobbs CS, Brenman JE, Aldape KD, Bredt DS, Israel MA (1995) Expression of nitric oxide synthase in human central nervous system tumors. Cancer Res 55: $727-730$

Feige U, Overwien B, Sorg C (1982) Purification of human blood monocytes by hypotonic density gradient centrifugation in Percoll. J Immunol Methods 54: $309-315$

Fujimoto H, Ando Y, Yamashita T, Terazaki H, Tanaka Y, Sasaki J, Matsumoto M, Suga M, Ando M (1997) Nitric oxide synthase activity in human lung cancer. Jpn J Cancer Res 88: 1190-1198

Gallo O, Masini E, Morbidelli L, Franchi A, Fini-Storchi I, Vergari WA, Ziche M (1998) Role of nitric oxide in angiogenesis and tumor progression in head and neck cancer. J Natl Cancer Inst 90: 587-596

Garvey EP, Oplinger JA, Furfine ES, Kiff RJ, Laszlo F, Whittle BJ, Knowles RG (1997) $1400 \mathrm{~W}$ is a slow, tight binding, and highly selective inhibitor of inducible nitric-oxide synthase in vitro and in vivo. J Biol Chem 272: $4959-4963$

Imamura H, Takao S, Aikou T (1994) A modified invasion-3-(4,5dimethylthiazole-2-yl)-2,5- diphenyltetrazolium bromide assay for quantitating tumor cell invasion. Cancer Res 54: 3620-3624

Jadeski LC, Hum KO, Chakraborty C, Lala PK (2000) Nitric oxide promotes murine mammary tumour growth and metastasis by stimulating tumour cell migration, invasiveness and angiogenesis. Int J Cancer 86: 30-39

Jadeski LC, Lala PK (1999) Nitric oxide synthase inhibition by N(G)-nitro-Larginine methyl ester inhibits tumor-induced angiogenesis in mammary tumors. Am J Pathol 155: 1381-1390

Keefer LK, Nims RW, Davies KM, Wink DA (1996) 'NONOates' (1-substituted diazen-1-ium-1,2-diolates) as nitric oxide donors: convenient nitric oxide dosage forms. Methods Enzymol 268: 281-293

Keller R, Geiges M, Keist R (1990) L-arginine-dependent reactive nitrogen intermediates as mediators of tumor cell killing by activated macrophages. Cancer Res 50: $1421-1425$
1996). In co-cultures of the human colorectal adenocarcinoma cell line HT-29 with human monocytes we found a similar strong induction of NOS II mRNA in the HT-29 cell line, but no change in the basal NOS II mRNA level in the monocytes. Therefore, the enhanced nitrite concentration in the co-culture supernatants probably result from NO synthesis in HT-29 cells, which has no obvious cytotoxic effect until $48 \mathrm{~h}$ of co-culture. It is known from rodents, that NO-derived reactive nitrogen intermediates (RNI) produced by macrophages are cytotoxic against tumour cells (Bogdan and Nathan, 1993). But the reported NOS activity in human tumour cell lines or tumour tissues is at least $1-2$ orders of magnitude lower than the enzyme activity associated with the cytotoxicity of rodent macrophages (Keller et al, 1990). The production of RNI by monocytes in the used co-culture model can not be proposed, since no relevant levels of RNI are produced before maturation of monocytes to macrophages (Martin and Edwards, 1993).

Tumour-associated macrophages are promoters of tumour growth and invasion by different ways. This study shows that pro-inflammatory cytokines induce NOS II expression and NO synthesis in tumour cells. NO promotes tumour progression by mechanisms like stimulation of angiogenesis (Jadeski and Lala, 1999), and as demonstrated in this study also by stimulation of invasiveness.

\section{ACKNOWLEDGEMENTS}

We thank Ms Ines Koch for her excellent technical assistance.

Kohn EC, Liotta LA (1995) Molecular insights into cancer invasion: strategies for prevention and intervention. Cancer Res 55: 1856-1862

Konur A, Krause SW, Rehli M, Kreutz M, Andreesen R (1996) Human monocytes induce a carcinoma cell line to secrete high amounts of nitric oxide. J Immunol 157: 2109-2115

Lagares-Garcia JA, Moore RA, Collier B, Heggere M, Diaz F, Qian F (2001) Nitric oxide synthase as a marker in colorectal carcinoma. Am Surg 67 $709-713$

Lala PK, Chakraborty C (2001) Role of nitric oxide in carcinogenesis and tumour progression. Lancet Oncol 2: 149-156

Martin JHJ, Edwards SW (1993) Changes in mechanisms of monocyte/ macrophage-mediated cytotoxicity during culture. J Immunol 150: $3478-3486$

Murrell GA, Jang D, Williams RJ (1995) Nitric oxide activates metalloprotease enzymes in articular cartilage. Biochem Biophys Res Commun 206: $15-21$

Orucevic A, Bechberger J, Green AM, Shapiro RA, Billiar TR, Lala PK (1999) Nitric-oxide production by murine mammary adenocarcinoma cells promotes tumor-cell invasiveness. Int J Cancer 81: 889-896

Tanaka H, Kijima H, Tokunaga T, Tajima T, Himeno S, Kenmochi T, Oshiba G, Kise Y, Nishi T, Chino O, Shimada H, Machimura T, Tanaka M, Makuuchi H (1999) Frequent expression of inducible nitric oxide synthase in esophageal squamous cell carcinomas. Int J Oncol 14: 1069-1073

Thomsen LL, Lawton FG, Knowles RG, Beesley JE, Riveros Moreno V, Moncada S (1994) Nitric oxide synthase activity in human gynecological cancer. Cancer Res 54: $1352-1354$

Thomsen LL, Miles DW (1998) Role of nitric oxide in tumour progression: lessons from human tumours. Cancer Metastasis Rev 17: 107-118

Thomsen LL, Miles DW, Happerfield L, Bobrow LG, Knowles RG, Moncada S (1995) Nitric oxide synthase activity in human breast cancer. Br J Cancer 72: $41-44$

Wink DA, Vodovotz Y, Laval J, Laval F, Dewhirst MW, Mitchell JB (1998) The multifaceted roles of nitric oxide in cancer. Carcinogenesis 19: $711-$ 721 
Witthoft T, Eckmann L, Kim JM, Kagnoff MF (1998) Enteroinvasive bacteria directly activate expression of iNOS and NO production in human colon epithelial cells. Am J Physiol 275: G564-G571

Xie K, Fidler IJ (1998) Therapy of cancer metastasis by activation of the inducible nitric oxide synthase. Cancer Metastasis Rev 17: 55-75
Yagihashi N, Kasajima H, Sugai S, Matsumoto K, Ebina Y, Morita T, Murakami T, Yagihashi S (2000) Increased in situ expression of nitric oxide synthase in human colorectal cancer. Virchows Arch 436: 109-114 